NEUROSIS IN SOCIETY 


\title{
NEUROSIS IN SOCIETY
}

\author{
ANDREW SIMS \\ Professor of Psychiatry \\ University of Leeds
}

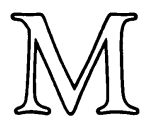


(c) Andrew Sims 1983

Softcover reprint of the hardcover 1st edition 1983

All rights reserved. No part of this publication may be reproduced or transmitted, in any form or by any means, without permission.

First published 1983 by

THE MACMILLAN PRESS LTD

London and Basingstoke

Companies and representatives throughout the world

ISBN 978-0-333-33515-4 ISBN 978-1-349-17113-2 (eBook)

DOI 10.1007/978-1-349-17113-2 


\title{
Contents
}

\author{
Foreword
}

1 What Is Neurosis? 1

Definition and Meaning 3

Illness or reaction $\quad 3$

Boundaries of neurosis 4

The characteristics of normality 5

Psychosis and neurosis 6

Operational and epidemiological definition 7

Behavioural and symptomatic definition $\quad 8$

Individual and social definition $\quad 9$

Why is neurosis important? $\quad 9$

Prevalence in the Whole Community 10

Stirling County survey 11

Subclinical neurosis syndrome $\quad 11$

Prevalence in Camberwell 13

Life-time Risk of Neurosis $\quad 13$

The effects of personality 14

Stress as provocation $\quad 15$

Expression of Neurosis in Different Cultures 16

Epidemic neuroses $\quad 16$

$\begin{array}{ll}\text { Cultural patterns } & 17\end{array}$

Classification of Neuroses $\quad 18$

Neurotic syndromes in the International Classification $\quad 18$

An inconsistent condition $\quad 19$

An American classification $\quad 20$

Neurosis from Different Perspectives $\quad 22$

2 The Evolution of an Idea $\quad 25$

The Mind and its Afflictions $\quad 26$

Springs of Action and Mechanisms of Behaviour $\quad 28$

People at Risk: Prone Personalities $\quad 30$

Treatments; Moral and Chemical 31

The Stigma of Neuroses $\quad 35$

3 An Illness that Needs Treatment 39

Why is Neurosis the Concern of Doctors? 39

Non-organic Symptoms 41

In what Sense is Neurosis a Disease? 42 
The Nature of Medical Consultation $\quad 43$

The Relationship in Treating Illness 45

Inter-disciplinary Treatment of Neurosis $\quad 47$

Psychogenic Illness in Hospital Settings 47

Neurosis in General Practice Patients 51

Neurosis and Physical Illness $\quad 53$

Psychosomatic Disorder 53

Pain $\quad 58$

$\begin{array}{ll}\text { Summary } & 59\end{array}$

4 Origins of Neurotic Behaviour 62

Genetics in Neuroses and Personality Disorders 63

Early Upbringing and Child Rearing $\quad 65$

Psychodynamic Aetiology $\quad 70$

Physical Determinants of Non-organic Disorder 72

Stress; the Balance Between Man and his Environment $\quad 74$

Social Factors Promoting Neuroses $\quad 76$

Learning Theory and the Development of Neurosis $\quad 78$

5 Course, Outcome and its Evaluation 82

Natural History $\quad 82$

Course and Outcome $\quad 83$

Age of onset $\quad 84$

Course through life $\quad 85$

Dependence upon drugs, alcohol, tobacco and people $\quad 87$

$\begin{array}{ll}\text { Neurosis to psychosis } & 88\end{array}$

$\begin{array}{ll}\text { Mortality } & 89\end{array}$

Evaluation of Severity and Outcome of Neurosis $\quad 92$

The need for assessment $\quad 92$

Instruments for evaluating neurosis $\quad 93$

$\begin{array}{ll}\text { Tracing } & 99\end{array}$

Interviewing at follow-up $\quad 99$

Studying the process of change $\quad 100$

Measuring outcome 101

The Neurotic Paradigm 103

6 The Phenomena of Neurotic Illness 109

Case report 109

The Clinical Assessment of Neurotic Symptoms 110

Self-experience in neurosis $\quad 111$

Bodily symptoms $\quad 116$

Experience of relationships $\quad 117$

The Neurotic Syndromes 119 
Anxiety states $\quad 119$

$\begin{array}{ll}\text { Hysteria } & 121\end{array}$

Phobic states $\quad 126$

$\begin{array}{ll}\text { Obsessive-compulsive disorders } & 128\end{array}$

Neurotic depression $\quad 130$

Neurasthenia 134

Depersonalisation syndrome $\quad 135$

$\begin{array}{ll}\text { Hypochondriasis } & 136\end{array}$

The Manifestation of Symptoms 137

7 Neurosis and Personality Disorder $\quad 139$

What is Personality Disorder? $\quad 139$

Development of personality $\quad 143$

Types of Personality Disorder 144

Paranoid personality disorder $\quad 144$

Affective personality disorder $\quad 145$

Schizoid personality disorder $\quad 145$

Explosive personality disorder $\quad 146$

Anankastic personality disorder $\quad 146$

Hysterical personality disorder $\quad 148$

Asthenic personality disorder $\quad 149$

Asocial personality disorder $\quad 149$

Assessment of Personality Disorder $\quad 150$

Reliability of diagnosis $\quad 150$

Differential diagnosis of personality disorder $\quad 151$

$\begin{array}{ll}\text { Neurosis and neuroticism } & 154\end{array}$

8 Social Aspects of Neurosis $\quad 156$

$\begin{array}{ll}\text { Work and Neurosis } & 157\end{array}$

$\begin{array}{ll}\text { Obtaining work } & 157\end{array}$

The neurotic in his role at work $\quad 158$

$\begin{array}{ll}\text { Job satisfaction } & 159\end{array}$

$\begin{array}{ll}\text { Stress at work } & 160\end{array}$

Unemployment and the threat of redundancy 161

$\begin{array}{ll}\text { Marital Dysfunction } & 161\end{array}$

Symptoms of a disordered marriage $\quad 162$

Environmental factors $\quad 165$

Problems of the unmarried $\quad 167$

$\begin{array}{ll}\text { Sexual pathology } & 167\end{array}$

The Neurotic Family and the Community 169

$\begin{array}{ll}\text { Development of the family } & 169\end{array}$

$\begin{array}{ll}\text { Conflict in the family } & 170\end{array}$

Neurosis and the local social structure $\quad 172$

$\begin{array}{ll}\text { Pathological Dependence } & 173\end{array}$ 
viii

Alcohol and drugs $\quad 173$

Other forms of dependence $\quad 175$

$\begin{array}{ll}\text { Social Neuroses } & 176\end{array}$

Housing conditions $\quad 176$

$\begin{array}{ll}\text { Aftermath neurosis } & 177\end{array}$

Communicated neurosis 180

Institutional neurosis $\quad 181$

Mind persuasion $\quad 182$

Compensation neurosis $\quad 183$

Forensic aspects of neurosis 184

The social phenomenon of self-poisoning 186

9 The Elderly Neurotic $\quad 191$

Late Onset and Chronic Neurosis in Old Age 193

Patterns of Neuroses in Late Life 194

Depression in the Elderly 194

Experience of Loss 196

$\begin{array}{ll}\text { Psychosocial Deprivation } & 196\end{array}$

Problems with Relationships 198

Work and Retirement $\quad 198$

Personality and Personality Disorder $\quad 199$

Alcoholism and Drug Dependence $\quad 200$

Treatment for the Elderly Neurotic $\quad 201$

Summary $\quad 202$

10 General Principles of Treatment 204

An Approach to Treatment 204

The patient's contribution to treatment 204

Why treat neurosis? 206

Aims of treatment $\quad 207$

$\begin{array}{ll}\text { Diagnosis } & 207\end{array}$

Patients and clients $\quad 208$

Science and medicine $\quad 208$

Treatment by Whom? $\quad 209$

Methods and Principles of Helping $\quad 211$

$\begin{array}{ll}\text { The non-directive approach } & 212\end{array}$

$\begin{array}{ll}\text { Coping and independence } & 213\end{array}$

Collusion and confrontation $\quad 214$

Insight and self-control $\quad 215$

The problem of guilt $\quad 217$

Options in treatment $\quad 218$

Preventive Action $\quad 219$

Improving the state of the individual within society 220

Research and the effects of treatment 222 
11 Methods of Treatment 224

Treatment by Psychotherapy 224

Dynamic psychotherapy $\quad 227$

Group psychotherapy 232

Role playing and psychodrama 233

Hypnotherapy and relaxation 234

Behavioural and Other Forms of Therapy 235

Behavioural modification $\quad 235$

Biofeedback $\quad 239$

Activity therapies $\quad 240$

Family therapy 241

Cognitive therapy 241

Treatment of Specific Conditions $\quad 242$

Alcoholism $\quad 242$

Anorexia nervosa $\quad 243$

Marital dysfunction $\quad 244$

Sexual dysfunction $\quad 245$

Neurosis in the elderly $\quad 246$

Social forms of Therapy 247

Manipulation and change $\quad 247$

Treatment milieu $\quad 248$

Psychiatric nursing 249

Treatment from outside Health and Social Services 250

The contract for social management 252

Chemotherapy and Physical Methods of Treatment 252

Function of drug treatment in neurosis 253

Action of minor tranquillisers and hypnotics 253

Antidepressants $\quad 255$

Electro-convulsive therapy and psychosurgery 257

A Treatment Plan for the Neurotic Patient 257

Further Reading (chapters 10 and 11) 261

Index 


\title{
Foreword
}

\author{
by \\ The Lord Taylor of Harlow, MD, FRCP, FRCGP, FFL
}

Good clinical medicine, whether it is concerned with body or mind, starts with the careful observation of disease patterns. Only when the natural history of a disease episode has been established can prognosis be reliable and the effect of treatment properly assessed.

Professor Andrew Sims is a naturalist-psychiatrist in the tradition of Thomas Sydenham. For many years, he has been observing the nature, varieties and course of psychiatric illness, with a special interest in the severe neuroses. He has established beyond doubt that the severe neuroses are serious and intractable diseases, which carry with them a substantial mortality risk, even if suicide is excluded. He has observed and charted the close interaction between neurosis and the community whether it be the wider community of work and society, or the closer community of the family. Within these frames of reference, he has reviewed the full range of possible treatment, to see how far each technique yields results which are acceptable both socially and medically.

In this important book, he records his own observations, set against the published experience of many others. Severe neurosis is a subject of great difficulty. Any clear account is. bound to be controversial if only because of the volume and diversity of speculative thinking in this field. Professor Sims sweeps through this confusion without being caught up in any particular dogma. He checks each assertion against the natural history of neurosis as he knows it, but leaves the reader to draw his own conclusions.

I have enjoyed particularly his accounts of the social neuroses, for example those caused by, or associated with, the Birmingham IRA bomb episodes. Today, he sees the epidemic neuroses spreading more rapidly than ever before, with the mass media as the vectors. He points out the mixed nature of many neuroses, with obsessional or hysterical features mixed with anxiety and depression. He quite rightly sees reactive or exogenous depression as a neurotic illness, the treatment of which is extremely difficult.

This is a book of great significance, to be read and pondered over by psychiatrists, physicians and general practitioners, as well as by those of the professions supplementary to medicine who have to deal with the neurotic in society. It should do much to improve the quality 
of care and understanding which the neurotic in society receives. It should also provide a springboard for further research, in particular for epidemiological studies. Sound epidemiology is the great enemy of unsound clinical speculation. The clear and honest picture which Professor Sims has painted provides a sound foundation on which future investigation of this difficult subject can be built.

House of Lords and Glyn Ceiriog, North Wales, 1982 